\title{
45 顔の印象と魅力を探る
}

\author{
東京大学 原島 博
}

Impression and Attractiveness of the Face

Hi rosh i HARASHIMA

(Faculty of Engineering. The University of Tokyo, Tokyo 113, Japan)

\section{1. 䝺とは何か}

我々は、生まれた時から「顔」とつきあってい る。朝、鏡の中にいる「顔」の機㜊がいいと、何 となくその日が楽しくなる。好き嫌いは別にして、 「顔」は生涯の友人なのである。

そして、「顔」は自分自身であある。プライド あるいはコンプレックスの源であり、「顔に泥を 塗られる」ことは、自分の尊览そのものが傷つけ られることを意味する。

さらに、「顔」はコミュニケーションの手段で あある。我々は、怒りの表情によって相手を威硳 し、微笑によって相手への好意を示す。顔によっ てその人の印象が決まることも多い。

「顔」は、心の動きを誢く空ですある。我々は、 顔とその表情によって、その人の感情や気分を読 み取ることができる。逆に政治家は作り笑いによ って、それを䜿命に隠そうとする。

\section{2. 学祭領域としての「影」}

このように記すと、筆者が顔を専門に研究する 心理学者のように見元るかる知れない。実は、筆 者が属しているのは工学部であり、尃門はテレビ 電話を中心とする画像通信なのである。ただし、 普通のテレビ電話ではなく、コンピュータグラフ
イックス技術を駆使した、次のような究極の通信 を夢みている。

テレビ電話では、当然ながら自分の顔を相手に 見せることになる。しかし例えば、早朝まだ化桩 していない時のテレビ電話には、かなりの人が抵 抗感を持っであろう。そのような時に、化粧した 自分の顔写真をまず一枚送って、その顔写真を動 かしながら相手とテレビ電話ができたら・・。

それには、受信側のコンピェータの中に、顔写 真を表面に張り付けた「顔の張り子」のようなる のを用意しておき、それを送信側から送られてき た動き情報に基づいて動かせばよい。これが筆者 が研究を進めている「知的画像符号化」の基本的 な考え方である。

工学の分野では、顔のコンピュータグラフィッ クスやアニメーション、あるいは顔の自動惩識な どを目的とした研究む進められている。さらにコ ンピュータやメディア技術の分野であ、最近顔へ の関心が高まりつつある。

例えば、コンピュータのモニターの画面内に人 間の顔をしたロボットが現れて、あたかむテレビ 電話で話すようにそのロボットと対話ができれば、 全くの初心者であ自由にコンピニータとつきあう ことが可能となろう。さらに、コンピュータの内 部状態がロボットの表情として見えるようになっ ていれば、文字どおり以心伝心のコミュニケーシ 
ョンが実現するか它知れない。

工学に限らず、顔を扱っている研究分野は多様 である。人類学、心理学、生理学、化栍学、人相 学、美容整形、齿科矯正、法医学、演劇、荎術、

- .

しかしながら、人間の顔面表情の研究は、そ机 を定量的かつ客観的に报う方法論がなく、従来の 研究はほとんどが単なる定性的な記述にとどまっ ていた。筆者らは、画像処理ならびにコンピュー タグラフィックスの手法を積極的に利用すること により、「顔の容貌と表情の分析合成システム」 を開発し、顔に関連する各種の感性コミュニケー ション研究に役立てることを考えている。以下、 システムの概要を説明する。

\section{3. 顛画像合成}

顔画像の分析合成システムでは、まず顔および 頭部に関古るモデルをいかなる形で用意し、これ を画像生成に利用するかが問題になる。

ここでは、顔立ち、すなわち頭と顔の形と目帛 口などの配置を、図10ような3次元楧造モデル で表現することとする。これはコンピュータグラ フィックスの分野でワイヤフレームモデル之呼ば 㣗ているすのに相当している。「張り子」の骨組 みであると考えてむよい。これに、例えば特定個 人の顔写真を投影して張りつけて、「張り子」の 肌つまり皮虑表面を与えれば、濃淡をるった顔画 像を生成することができる。

このようにして、ひとたび張り子が用意されれ ば、任意方向から見た顔画像を合成するこしすで きる。図2にモナリザの横顔の合成例を示す。

\section{4. 表情合成}

次の問題は、㳫り子すなわち顔のモデルに表情 をつけることである。一般に表情は、顔面筋の伸 縮による目や口周辺の特徴点の動きにより特徴づ けられる。従って、この動きをパラメータ化して、 構造モデルを変形させれば、表情をもつ顔画像が 合成できる。
顔の特徽点の動きによって顔面表情を記述する 試みとして、Ekman とFriesen による F A C S (Facial Action Coding System)[3]が知ら机てい る。そこでは、表情変化にともなう人間の顔の動 きを44はどのAU（Action Unit）と呼ばれる 基本的な動きに分解している。そして、あらゆる 表情は、これらのAUの組み合わせで表現できる とされている。

これをコンピュータ上で実現し、そ狄ぞれのA Uの強さによって、3 次元構造モデルを変形させ、 あわせて皮眉も移動するようにしておけば、任意 の表情を効率よく合成することができる。

本研究では、現在 34 通りのA Uが実現されて いる[4]。A Uによる表情の合成例を図 3 に示す。

\section{5. 容貌合成}

F A C S による表情付けは、檴造モデルの幾何 学的な変形に基づくあのであった。しかし、顔の 特徵は、必ずしも幾何学的な形状だけではない。 顔の陰影あるいは皮虑の状態なども、顔を特幑づ ける重要な要素である。顔は、これらを統合した 容貌パターンとして把える必要がある。

このような顔の容貌パターンはどのようにして パラメータ化できるのであろうか。その一つの解 答として、本研究では、次のような基底顔画像展 開によるバラメータ化を試みている $[5] 。$

信号解析の分野では、時間波形 $\mathrm{f}(\mathrm{t})$ を、基底 波形の組 $\phi_{k}(\mathrm{t})$ で展開して、

$$
f(t)=\sum_{k} C_{k} \phi_{k}(t)
$$

亡表わし、その展開係数 $\mathrm{C}_{\mathrm{k}}$ を波形のパラメータ として用いることが多い。ここに、基底を正弦波 とすれば、よく知られているフーリ工解析となる。

顔画像の場合は、基底そのものも顔画像として、 複数枚の異なる基底顔画像を用意しておき、その 荷重結合で新たな顔画像を表現することが考えら れる。しかし、単に画苯レベルで荷重和をとって あ、合成される画像はぼけたものになってしまう。 そこで、つぎのような工夫を加えている。 
（1）まず、顔の各点の座標值（例えば構造モデルの 各頂点の座標値）に対して荷重和を計算して、 目的とする顔形状を得る。

（2）次に、基底顔画像の濃淡パターンを幾何学的に 変形して、すべて(1)で得られた顔形状と同じ にする。

(3)同じ形状の基底顔画像のそれぞれの画素値に対

して荷重和を計算して、顔画像を合成する。

こうして基底顔画像の組み合わせにより自然な顔 画像が得られる。図44、この手法で合成された 各種の職業の男性の平均顔である。

与えられた顔画像を基底顔画像の荷重和で表し、 そのパラメー夕（荷重係数：式(1)の（k に相当） を求めることもできる。その際、基底顔画像は互 いに直交していることが望ましい。この直交化は、 主成分分析の手法を用いて実現できる [5]。

この手法は、表情合成にも利用できる。例えば、 「笑い」と「泣き」の基底顔画像を用意しておき、 その荷重結合により中間の表情を合成すれば、「 泣き笑い」の表情が得ら机る。

\section{6. 感情・朾象表現}

このような表情の分析合成の手法を用いて、人 間の感情を分析すること、あるいは逆に感情をも つ顔画像を合成することる夢ではない。

例えば、心理学の分野では、人間の基本感情は、 警き、恐怖、娧悪、怒り、喜び、悲しみの6 通り あるとされている。したがって、この6通りの表 情を基底顔画像として用意しておき、それらを荷 重合成す扎ば、中間の感情をすつ顔画像が合成で きよう。

一方、4.あるいは 5 .で述べた表情のパラメー 夕化手法を用いると、顔画像加ら得られたそれぞ れの表情を、空間内の点として位置づけることが できる。例えば、F A C S を用いると、A Uの個 数に等しい 44 次元筀間が構成され、表情は AU の強さを座標とする点として位置づけられる。基 底顔画像から表情を合成する場合は、荷重係数そ のものが、空間内の点の座標となる。

このような表情空間あるいは 5 .で述べた基底を
もつ顔の容貌空間と心理学的な知見 [6]の対応が調 べられれば、感情と顔面表情、性格と顔容貌など の関係が明らかにならう。現在、予備検討の段階 ではあるが、「苦虫を嚙み潰す」などの感情語と 表情空間の関係、「優しい顔」などの顔印象語と 顔容貌空間の関係を探っている。

\section{7. 感性コミュニケーション学へ}

以上、顔画像と表情の分析合成システムの概姴 について述べた。この研究は、最近、思わ方向 へ色々な展開を見せている。

例えば、警察のモンタージュ写真の合成へ応用 すれば、任意の句き、任意の表情、さらには任意 の動きのある手配ビデオを作ることができる。

むちろん、心理学研究への応用む考えられる。 実は、この研究を一番喜んだのは、若手の心理学 者グループであった。上記のシステムを心理学の 研究道具として使うと、表情パラメータに基づい て実際に顔面表情を合成しながら、人間の表情認 知構造などを探ることができる。

また、顔の表情の研究を通じて、人間の感性コ ミュニケーションそのあのへ迫れないかとの期待 あある。昨年度よりスタートした文部省の重点領 域研究プロジェクト「感性情報処理の情報学・心 理学的研究」でも、この顔研究が一つの柱になっ ている。

あとすと日本人は、表情による感性コミュニケ 一ションが下手な民族であると言わ机ている。感 性豊かなヒューマンコミュニケーション社会へ向 けて、この研究を通じて少しであ貢献できたらと 考えている。

\section{参考文献}

[ 1]原鼠博：知的画像符号化と知的通信，テレビ ジョン学会誌。 42, 6 (1988) pp. 519-525

[ 2] 原島博:知的画像符号化と映像口ボット技術， 計測と制御，30，6(1991) pp.478-484

[ 3] P. Ekman, and W. V.Friesen: Facial Action Coding System, Consulting Psycologists 
Press (1977)

[ 4]崔, 原島,武部：顔の 3 次元モデルに基づく表 情の記述と合成, 電子情報通信学会論文誌 A, J73-A, 7 (1990) pp. 1270-1280

[ 5] 原島, 岡崎, 崔, 武部 : 顔画像の主成分分析とそ の応用, 電子情報通信学会技術研究報告, HC
90-28 (1991) pp. 25-33

[ 6]福井康之: 感情の心理学, 川島書店 (1990)

[ 7]原島博 : 顔, 表情, そして感情一映像ロボット 技術からのアプローチー, 日本機械学会誌, 95, 883 (1992) pp. 503-507

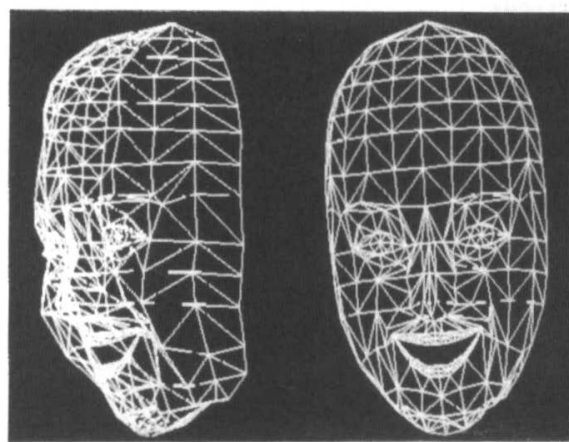

図 1

ワイヤフレームモデル

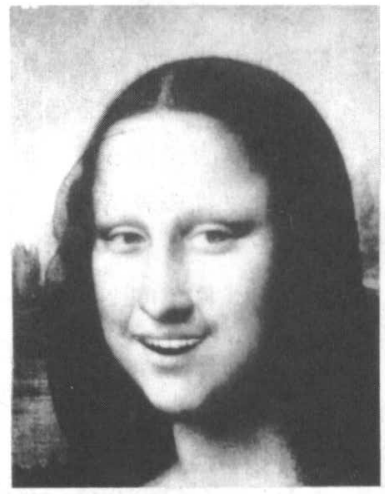

図 3 A U の組合せによる表情の合成（AU6+12+26）

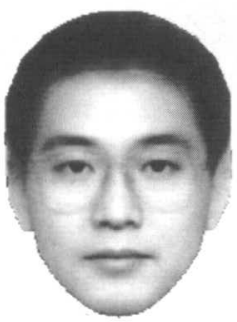

銀行員 (13人)

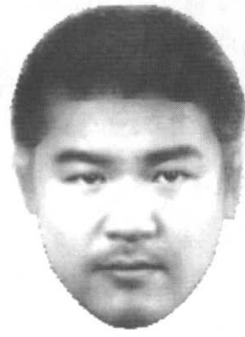

プロレスラー(11人)

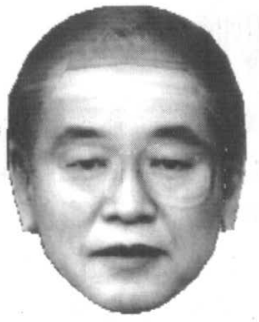

政治家(10人)

図 4 職業別平均の容貌の合成 